\title{
UK Citizenship in the Early 21st Century: Earning and Losing the Right to Stay
}

Citoyenneté britannique et droit de résidence au début du XXİ̀me siècle

\section{Catherine Puzzo}

\section{OpenEdition}

1 Journals

Electronic version

URL: http://journals.openedition.org/rfcb/750

DOI: $10.4000 / \mathrm{rfcb} .750$

ISSN: 2429-4373

Publisher

CRECIB - Centre de recherche et d'études en civilisation britannique

\section{Electronic reference}

Catherine Puzzo, "UK Citizenship in the Early 21st Century: Earning and Losing the Right to Stay », Revue Française de Civilisation Britannique [Online], XXI-1 | 2016, Online since 11 July 2016, connection on 10 December 2020. URL : http://journals.openedition.org/rfcb/750 ; DOI : https://doi.org/10.4000/ rfcb.750

This text was automatically generated on 10 December 2020.

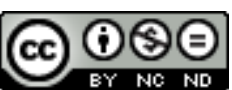

Revue française de civilisation britannique est mis à disposition selon les termes de la licence Creative Commons Attribution - Pas d'Utilisation Commerciale - Pas de Modification 4.0 International. 


\title{
UK Citizenship in the Early 21st Century: Earning and Losing the Right to Stay
}

\author{
Citoyenneté britannique et droit de résidence au début du XXI ${ }^{e ̀ m e}$ siècle
}

\author{
Catherine Puzzo
}

\section{Introduction}

1 From the mid-1990s Britain has been a popular destination for migrants and the country has experienced rising trends of people migrating to the UK for different reasons. Today Britain's foreign-born population includes economic migrants from and outside the European Economic Area (EEA), asylum seekers, students, visitors and irregulars. Their numbers have risen swiftly and steadily so that immigration has been exceeding emigration by more than 100,000 in every year since the turn of the century. ${ }^{1}$ Although the UK has been a multi-national and multicultural society for quite a long time now, over the last fifteen years intense debates on immigration and citizenship have led to several policy reviews and significant reforms of British citizenship. The policy developments presented below span the 1997-2014 period during which modifications to the processes of settlement but also of acquiring and losing UK citizenship were implemented. Governmental instruments of migration policy narrowed down the number of "acceptable migrants" by way of stricter border controls to detect irregulars and measures to fight human trafficking, the implementation of the points based system to replace work permits, the introduction of a net cap on migrant workers, the delivery of fewer student visas, the rapid processing of asylum requests and a greater use of deportation orders to expel failed asylum seekers and irregulars from the country.

The purpose of this paper is to explore UK citizenship in its political and institutional dimensions and more specifically, to analyse the type of relationship or "point of connection' that successive governments sought to define between aspirant citizens and the British state. Naturalisation in the UK brings with it not only the right to live 
permanently but also the impossibility for the British state to deport somebody. As such holding UK citizenship remains crucial for many migrants and their families wishing to remove the possible threat of the revocation of the settled status and the possible deportation order that may follow. In the period under study the legal requirements to acquire British citizenship were modified on several occasions so that today, the concept of British citizenship appears as a multi-layered one. Formally citizenship has been conceived as a positive demonstration of applicants' identification with Britain: taking of language and UK Life tests and participation in the citizenship ceremonies. It is clear that since the mid-1990s the renewed emphasis on citizenship has testified to a perceived lack of integration of some communities and policy changes have been driven by the desire to change foreign individuals' relation to the British state. Governments also showed their clear intention to shape the contours of an ideal 'foreign' population, able and willing to integrate into British society and discourage and potentially reject those deemed to constitute a threat (be it economic, social or terrorist) to Britain's interests. In that respect denaturalization, that is the stripping of British citizenship by British authorities, reminds us that conferring or removing UK citizenship remains a state power and that acquiring British citizenship is not a right but a privilege in the hands of the executive.

\section{Citizenship as a right or a privilege? Political discourses and legal requirements}

3 Questions of nationality are related to immigration law which regulates the legal rights and responsibilities of different categories of migrants, so that the right to acquire British citizenship is highly dependent upon one's legal immigration status. Although it would be beyond the scope of this paper to dwell on the many reforms in the field of immigration policy, some of the objectives and implications of citizenship policy are tightly connected to the immigration agenda. In 2014, just 125,800 foreign residents became British citizens through naturalisation, a significant decrease compared to the average of 195,800 per year over the 2009-2013 period. ${ }^{2}$ Amid concerns about integration and social cohesion, the Labour governments and the Coalition developed a citizenship agenda centred on a reconceptualization of British identity that would-be citizens can "attain by 'internalising' $a$ set of core values". ${ }^{3}$ Accordingly governments modified the legal procedure and practice through several pieces of legislation: Immigration, Nationality and Asylum Act of 2002, Asylum and Immigration Act of 2004, Immigration, Nationality and Asylum Act of 2006, Borders, Citizenship and Immigration Act of 2009 and Immigration Act of 2014.

When coming into office New Labour adopted a distinctive approach to modernize Britain which included an updating of citizenship in their political project and a first attempt to define ideal British citizens. As John Clarke argued "New Labour's ideal citizens are moralized, choice-making, self-directing subjects". ${ }_{4}^{4}$ Following the Crick report (1998), citizenship education was introduced in English secondary schools and the Advisory Board on Naturalisation and Integration (ABNII) was set up to work on the creation of language and citizenship courses and tests for would-be citizens. The disturbances of the summer 2001 and the Cantle report commissioned to make recommendations on social cohesion showed the government's main concern to promote common citizenship between different ethnic communities. It "emphasised the importance of promoting a 'meaningful concept of citizenship". ${ }^{5}$ As Home Secretary Blunkett asserted: "We need to educate new migrants in citizenship and help them to develop an understanding of our language, democracy 
and culture" ${ }^{6}$ The 2002 White Paper "Safe Haven, Secure Borders" (Home Office 2002) that followed proposed an inclusive version of the concept of citizenship based on a common identity with essential attributes to which people should identify. The text insisted on the rights and duties attached to UK citizenship defined in terms of belonging to the 'nation' and focused primarily on the nature and extent of citizen behaviours. ${ }^{7}$ The Home Office recommended to abandon the "low-key and bureaucratic approach which the UK has adopted to the acquisition of British citizenship". The Nationality, Immigration and Asylum Act 2002 made citizenship ceremonies mandatory, thereby creating a new legal condition in the acquisition of British citizenship (see infra).

5 Five years later, in July 2007 in its Green Paper The Governance of Britain, the fourth Labour government reassessed the nature of the links between its citizens and the state. The concept of citizenship was further explored within the process of naturalisation to move beyond the primary definition of citizenship as simply a formal legal status so as to include a prescriptive dimension where 'formal citizenship' would be reconciled to 'substantive citizenship'. Such reflexion was born after the London bombings of July 2005, the re-emergence of the terrorist threat in the summer of 2006 (with the thwarting of planned bomb attacks on several transatlantic flights) and also the Islamic veil controversy triggered off by Labour leader Jack Straw. Queries were raised in the political, social but also academic spheres on the scope of British multiculturalism but also on its perceived failures. In the governmental view there was a growing feeling that more had to be done in the fields of the politics of belonging and the management of national boundaries. ${ }^{8}$ Although the governmental rhetoric acknowledged the diversity of the different communities living in the UK, it also insisted on a supreme identity deriving from a "multicultural construction of British identity":

Each of us possesses multiple identities because we define ourselves in different ways depending on the factors that matter most to us. Factors such as gender, race, ethnicity, age, disability, class and faith are shared with some and different from others. But in addition to these there is a national identity that we can all hold in common: the overarching factor - British citizenship - that brings the nation together. ${ }^{10}$

6 Yet such conception is prescriptive and entailed the revision of British citizenship to adapt it to 'the rights and responsibilities' already foreshadowed in the 2002 text. To the government it was time to devise clearer criteria on citizenship acquisition and to have them implemented through detailed injunctions and formal rules. They pointed out that the concept had been overstretched in some occasions so as to include "everything and nothing at the same time" ${ }^{11}$ :

The Government believes that a clearer definition of citizenship would give people a better sense of their British identity in a globalised world. British citizenship and the rights and responsibilities that accompany it - needs to be valued and meaningful..$^{12}$

7 The next step was the publication of a governmental report in February 2008, entitled The Path to Citizenship: next steps in reforming the immigration system, followed by the passing of the Borders, Citizenship and Immigration Act 2009. The new act replaced citizenship acquisition within the broader framework of migration policies which led to a strengthening of border controls (in particular with new powers for customs officials and immigration officers) and extended the time it takes to gain citizenship. More significantly the text broke the link between length of residence, right to settlement and naturalisation. ${ }^{13}$ It amended the rules on naturalisation to reduce the number of 
immigrants allowed to remain permanently: "A bill...to ensure that newcomers to the United Kingdom earn the right to stay" (emphasis mine). UK citizenship was conceived as the final step in the journey made by migrants who had decided to come to Britain. Newcomers were first granted a temporary residence status (for a period up to 5 years), then allowed to progress to probationary citizenship (for a minimum of 12 months) to finally reach permanent residence, i.e. British citizenship. Conditions were attached to probationary citizenship, in particular provisions stipulated that migrants were enjoined to "make the right contribution to the country". Critics pointed out that the new conditions were going to lead many to lose their entitlement to remain in the UK. ${ }^{14}$ The limits of the 2009 act were clear making it longer and harder for migrants to become settled and gain British citizenship. The introduction of the 'probationary period' in the route to citizenship was meant to prevent migrants from having full access to a range of benefits available to permanently settled foreign nationals. The notion of 'active participation/contribution' to British society was particularly ambiguous. Applicants were required to prove they were of good character and that they were good taxpayers. It was also about demonstrating some sort of positive interaction with the local community. ${ }^{15}$ As Anderson points out "the community of value is populated not simply by citizens but by Good citizens, imagined law-abiding and hard-working members of stable and respectable families". ${ }^{16}$ Since then, the moralistic connotations attached to the acquisition of British citizenship have had a 'utilitarian' dimension praising the economic worthiness of certain categories of migrants.

8 The coalition government sought to simplify the system they inherited; the probationary stage, deemed too complex and bureaucratic was abandoned in July 2011 and so was the concept of 'active citizenship' which was meant to entice migrants doing volunteering in their community. ${ }^{17}$ This abandon may seem incoherent with the Big Society agenda which encouraged the civil society and local communities in particular to engage and be part of policy change. The Big Society concept was aimed at motivating participation through various forms but the Home Office's decision to drop the 'active citizenship' requirement implicitly excluded parts of the foreign population from the Big Society agenda.

The latest reform on the conditions to acquire British citizenship has not modified the overwhelming spirit of the definition, citizenship under the coalition and now the Conservative government remains prescriptive and utilitarian: the right to stay must still be 'earned' by prospective citizens. The moral and economic worthiness of some wouldbe citizens remains a crucial requirement to become part of the national community. Quite significantly in December 2012 the Cameron-Clegg administration sought to reinforce the weight of 'the good character' requirement when assessing applications for UK citizenship. The requirement was stipulated in the British Nationality Act of 1981 but was never properly defined, nor was any statutory guidance issued as to how this should be interpreted or applied in practice. In December 2007 in a Home Office announcement the criterion was related to the question of criminal convictions and since then it has been used more often than not by case workers when rejecting applications for naturalisation. Refusals of naturalisation applications based on the failure to meet 'the good character requirement' accounted for $34 \%$ of all refusals in 2014, a steady increase since 2010 ( $29 \%$ of all refusals). ${ }^{18}$

10 More recently in an effort to introduce transparency in its practice the Home Office published a series of instructions to its citizenship officers on how to interpret 'the good character' requirement when assessing citizenship applications. ${ }^{19}$ In particular 
instructions have been given to check: (i) the criminal record of the applicants, whether laws have not been respected or are not going to be respected (!), (ii) taxes have not been paid, (iii) activities in the community have not been adequate, (iv) deception has been used in the dealings with the UK government, (v) the applicant has been involved in notorious activities.

The renewed emphasis on citizenship in UK politics was meant to strengthen "a sense of common citizenship as a way of building social cohesion". ${ }^{20}$ Such concern was born in the context of a very fast changing societal landscape and led to debates on the pertinence of the multicultural model and on the ways to ensure that would-be citizens would abide by the democratic values of the country.

\section{Earning the right to stay: commitment and identification with Britain's values}

The significance of becoming a British citizen has been underpinned by the idea that " citizenship is more esteemed and valued when it is earned, not given". ${ }^{21}$ In line with the "earned citizenship' framework and the ideal of a 'committed' British citizen, future citizens have been invited to take part in a dynamic political process and not simply be the mere recipient/subject of a bureaucratic procedure..$^{22}$ The acquisition of citizenship has been more arduous, not anymore an automatic right conferred after a few years of residence in the UK as it was the case a decade before. Governments have intended to make it more onerous and longer for migrants to secure rights in the name of security concerns in particular. The acquisition of UK citizenship is conditional upon progressing successfully through various stages and it is a demanding process which requires, until the final stage with the participation in the citizenship ceremony, the individual's full commitment to the naturalisation procedure (see below). However the system does not offer many alternatives to those who do not apply for citizenship, those who do not meet the criteria (and will never do) or fail to satisfy the tests. In the governmental perspective the naturalisation procedure remains a privilege and not a right; it has an exclusionary dimension, which in the end threatens the permanence of several categories of migrants who do not fit in the normative requisites: failed asylum seekers, students, irregulars, overstayers, those with a criminal conviction. The rules contribute to perpetuate the old dichotomy between deserving and undeserving migrants: “Good migrants' are seen as worthy of British citizenship, whereas 'bad migrants' are seen as unworthy". ${ }^{23}$ Eligibility to naturalize is closely correlated to the legislation on entry, as exemplified by the case of students and those with temporary visas who cannot accumulate sufficient time toward fulfilling residency requirements. Anderson uses the term 'failed citizens' "to allude to those individuals and groups who are imagined as incapable of achieving, or failing to live up to, national ideals". ${ }^{24}$ While she alludes to other categories of migrants than students, irregulars and failed asylum seekers, it could be argued that there has been a deliberate attempt to create categories of 'failed would-be citizens' in the name of economic and social worthiness. This is epitomized by Kiwan who stress that "a 'moral' conception of citizenship is invoked in the notion of 'good' citizen predicated on primarily economic ground". ${ }^{25}$ Her postulate is related to her analysis of the implications for citizenship of the highly skilled 'guest-workers' programme when implemented in 2010, but it was still valid four years later to depict the Coalition citizenship agenda. In that respect the governmental rhetoric of acquiring citizenship drew on the notion of a deal, a contract concluded 
between newcomers/aspirant-citizens and the State, one which should put on a par the aspirant citizen and the State:

[T] here is a deal for citizenship. This is a country of liberty and tolerance, opportunity and diversity-and these values are reinforced by the expectation that all who live here should learn our language, play by the rules, obey the law and contribute to the community. ${ }^{26}$

Formally the deal has had a twofold dimension: the testing of immigrants' mastery of the national language and their compliance with a set of distinctive 'national' values.

The knowledge of English has been for candidates a longstanding criterion in their application for naturalisation. It had been stipulated in the British Nationality Act 1981 but it was a condition among others like the absence of any criminal conviction and was not rigorously enforced up to the Labour years. In the wake of the 2001 summer riots, the terrorist attacks of September 2001 and following the recommendations made by different commissions (2003 Advisory Group's report, Crick Report 2002/03) the second Blair government laid stress on the necessity for future citizens to have a good command of the English language. Quite explicitly the linguistic requirement in the 2002 Nationality, Immigration and Asylum Act had an immediate short-term economic objective: to fill the needs of the domestic labour market, at a time when skilled migrants and professionals were more than welcome to contribute to the economic development of the country. Linguistic assimilation was also deemed essential to strengthen cohesiveness and since then the linguistic competence has been an absolute precondition for acceptance. ${ }^{27}$ There has been broad ministerial acceptance across the political spectrum that 'shared values' and a good command of the English language are perfect indicators of 'integration' in the UK:

The requirement to have an adequate understanding of English needs to mean something, and needs to be supplemented by a level of knowledge of what it means to be a citizen of modern, democratic Britain. (...) We are developing new types of courses especially suited to the needs of migrants: English language courses which use teaching materials based on the concept of citizenship; courses specifically about citizenship for people who already have an adequate English but need to know more about what it means to live in this country and contribute to this community. ${ }^{28}$

There is now agreement with the proposition I made some time ago that for new citizens, learning English should be a requirement. New citizens should have an understanding of our history and our culture..$^{29}$

Real integration takes time. That's why, when there have been significant numbers of new people arriving in neighbourhoods perhaps not able to speak the same language as those living there, on occasions not really wanting or even willing to integrate, that has created a kind of discomfort and disjointedness in some neighbourhoods. ${ }^{30}$

Since 2005 the linguistic proficiency of future citizens has been certified by the ESOL Test Entry Three (English for Speakers of Other Languages). This minimum level of English means that candidates must be able to hold a conversation on whatever subject in an acceptable English, even if it is not perfect. ${ }^{31}$ The advantages of the British official ESOL is that it has a clearly defined linguistic level and is implemented coherently and consistently across the UK. Dina Kiwan makes a positive appraisal of the system, arguing that:

[T] he English language requirements is not intended to be a hurdle to the acquisition of citizenship; rather it is the first step to communicating and 
participating with one's fellow citizens, learning and integrating into a new culture. in particular associations defending immigrants' rights (see Joint Council for the Welfare of Immigrants, Immigration Law Practitioners Association) who stress that the test is apprehended as a mixed blessing by migrants. Criticisms have pointed out that these tests are particularly demanding for some categories of foreigners, namely illiterate candidates and those with a poor educational background and particularly women who in some parts of the world may not have had access to any elementary education. The financial aspect should not be undervalued for the fees to pay for the tests and the cost of the language training may be considered as deterring elements in the path to integration. Furthermore since September 2011 the effects of the budgetary cuts in funding ESOL courses have proven another disincentive to plan acquiring citizenship. Under the current scheme free places are only allocated to those on jobseeker's allowance or employment support allowance (that is, benefits paid to those actively seeking work).

By the end of 2005 the requirement to 'share values' had become salient in the wake of the London bombings (July) and the Lozells riots (October). Deep concerns over a perceived lack of integration was prominent in public discourse. The government's response to the 2007 report of the Commission on Integration and Cohesion (2008) was clear in that respect:

The Border and Immigration Agency is reviewing how the process of becoming a citizen can enhance the integration of individual migrants into UK society. This includes consideration of issues such as what are the values that newcomers should be committed to. ${ }^{33}$

The UK Life test modified on several occasions requires candidates to answer a series of questions based on a Home Office handbook: Life in the United Kingdom: A Journey to Citizenship (2004, 2005, 2007, 2013 editions). The terms 'comprehension, knowledge of a foreign language' are to be understood in their etymological and socio-cultural dimensions. The concept of 'life in the UK' is used in a broad meaning to cover, in a condensed version, events pertaining to the history of the UK but also elements of geography, politics and literature. As of March 2013 the latest version of the UK Life Test has laid the emphasis on applicants' mastery of British culture and recent historical developments (in relation to devolution for example) rather than on their knowledge of British daily life as it was the case in the former versions:

It is a move away from the old one - stuff on rights, practical information that has little to do with British culture - to one that is clear about responsibilities and requires people to have a grounding in our history. ${ }^{34}$

Experts have accused the new test of many flaws: "impractical, irrelevant, trivial, gender imbalanced, outdated and ineffective". ${ }^{35}$ Clearly it is aimed at an educated (if not highly educated) migrant population, those who, in the view of the government, are most welcome to remain in the UK. The relatively high level of the tests is in line with the wider framework on immigration control that successive governments have been implementing: strict selection to accept in the UK only those highly skilled migrants who can bring specific benefits to the United Kingdom. Both tests have put the onus on the applicants to demonstrate their sufficient knowledge and their ability to integrate. They remain closely connected to the wider agenda on immigration control. 
a decade ago, there was not any public ceremony celebrating the incorporation and the belonging of the new British citizens to their new country, contrary to what exists in the US and Canada for example. Together with the language and UK Life Test, the ceremonies were born in the aftermath of the 2001 civil disturbances and terror threats when the Labour governments sought to reinforce their national models of integration linking their citizenship regulations to "the politics of belonging and the management of national boundaries" ${ }^{36}$ Within the larger context of globalisation and increased, faster rates of immigration the creation of these ceremonies was also underpinned by the intention of the British state to assert its sovereignty over newcomers.

Britain's case is not isolated as testified by the development of citizenship ceremonies in other European countries like France, the Netherlands or Denmark during the same decade. The political roots of the development of these ceremonies lie in part in the recommendations made by the European Commission which encouraged European states to celebrate officially the naturalisation of their new citizens according to the motto " United within diversity". ${ }^{37}$ The European Ministerial Conference on Integration in November 2008 endorsed the proposal and recommended:

[T]o establish ambitious integration policies, to stress respect for the identities of the Member States and the European Union and for their fundamental values, such as human rights, freedom of opinion, democracy, tolerance, equality between men and women, and the compulsory schooling of children. ${ }^{38}$

In Britain when the first ceremonies were created, they were presented as a way to (i) disentangle a purely administrative procedure of registering citizenship from its bureaucratic characteristics and (ii) as an occasion given to migrants to publicly proclaim the choice they had made, embodying the concept of a voluntarist integration. ${ }^{39}$

The first citizens to participate in a citizenship ceremony were reminded of this two-fold dimension in the opening discourse made by Home Secretary David Blunkett in 2004:

Becoming a British citizen is a significant life event. The Government intends to make gaining British citizenship meaningful and celebratory rather than simply a bureaucratic process. New citizenship ceremonies will help people mark this important event. We want British citizenship to embrace positively the diversity of background, culture and faiths that living in modern Britain involves. ${ }^{40}$

Following the American and Canadian models the British have made the choice to include the ceremony in the process of naturalisation, hence giving the pledge sworn by applicants its full legal significance. Any candidate, above 18, who has received their invitation to participate in such a ceremony must swear an oath/affirmation of allegiance to Her Majesty the Queen and a pledge of loyalty to the UK. These declarations are made aloud simultaneously by all the candidates-citizens. ${ }^{41}$ Their significance was recalled by the Home Secretary in the Commons:

We may all have a slightly different interpretation of what they might be (i.e. the values we all attach to British citizenship), but I am confident that Members of this House would agree that this is encapsulated by the oath that naturalized citizens take when they attend their citizenship ceremonies. ${ }^{42}$

The unfolding of these ceremonies features a combination of legal characteristics (the swearing of a pledge/oath of allegiance) and strong symbolic elements such as the display of national and European flags and the playing of the national anthems. Quite early, the Home Office advised local authorities on the text of the welcoming speeches, suggesting what should be read to participants: 
On behalf of the Government of Her Majesty Queen Elisabeth the Second and (local authority) I would like to welcome you all here today to (venue) for this citizenship ceremony. This for (many of you) is the final step in the process of becoming a British citizen, which will welcome you to this nation and community. The citizenship ceremony is a rite of passage that formally welcomes those who wish to join us into full membership of the British family, and into citizenship of the United Kingdom, a state built on a union of nations, beliefs and common civic values. We are here today to extend this welcome to you and to confer the honour of citizenship upon you. ${ }^{43}$

26 Except for the first ceremonies that hosted governmental members, nowadays all of these opening discourses are made by local citizenship officers whose discursive strategies and rhetorical devices converge. There may be local variations as to the contents to adapt to the regional context and to the origins of the participants. ${ }^{44}$ Standardized speeches and texts are meant to ease and simplify the procedure even though the overuse of symbolic terms testify to the solemnity that the state intends to give to these ceremonies. The rituals should embody the enriching links between the new citizens and the state:

I think the new ceremonies across the country will be the answer to those who fear difference, who fear the diversity which comes with migration of people coming across the world to live in our community and sends a very clear message that those who choose to be part of the family are committing themselves. ${ }^{45}$

Becoming a British citizen is a milestone event in an individual's life - we have recognised the importance of the event by introducing citizenship ceremonies which celebrate the act of becoming a British citizen. An understanding of the British language and our way of life is vital. ${ }^{46}$

Ten years after the celebration of the first citizenship ceremony there has certainly been a gradual cooling of enthusiasm for these rituals. Local authorities organise them on a regular basis but they have become an administrative process, "albeit an important and celebratory one". ${ }^{47}$

\section{Losing the right to stay: denaturalisation and the state power to deprive}

Holding citizenship means having a protected legal status under international law and the right to a nationality is guaranteed by article 15 of the 1948 Universal Declaration of Human Rights. ${ }^{48}$ Yet, the UK has long retained the power to deprive somebody of his/her citizenship, a topic explored by Gibney in his article on the historical development of denaturalisation. ${ }^{49}$ As was argued in the first part, holding citizenship has been construed as a privilege, not a right, which is why "denaturalisation affirms citizenship as a privilege, one that is conditional on a certain standard of behaviour"..$^{50}$ In recent years Home Secretaries have been exercising more and more their power to strip people of their British citizenship and withdraw passport facilities for those individuals suspected of having been involved in terrorist activities (especially overseas) or considered to be a threat to national security (see table below). This discretionary power has been expanded in the 2014 Immigration Act (clause 60). The text of the new clause on deprivation aroused animated debates in the Commons and the Lords during the winter of 2013-2014 and led to the government's defeat at report stage in the House of Lords. ${ }^{51}$ The clause was inserted in the wake of a landmark case lost by the British government in 2013, Secr. Of State for the Home Department v. Al-Jedda ${ }^{52}$ the first case on deprivation of citizenship to reach the Supreme Court. The judgement based on section 40 of the British Nationality 
Act of 1981 which prohibits the Home Secretary to deprive somebody of their British citizenship if that would render the person stateless, irritated the executive profoundly and led Teresa May to introduce at a late stage an amendment on denaturalisation in the 2014 immigration bill. The government's main argument to back up their proposal was that British citizenship is not a right but a privilege. Mark Harper, then immigration minister stated rather clearly that

[T] hose who threaten this country's security put us all at risk. This government will take all necessary steps to protect the public. Citizenship is a privilege, not a right. These proposals will strengthen the Home Secretary's powers to ensure that very dangerous individuals can be excluded if it is in the public interest to do so. ${ }^{53}$

洒 Nationality Act 1981 and stipulates the conditions under which an order can be made by the Home Secretary to deprive a person of their British citizenship. The clause provides that (i) a British person can be deprived of his/her citizenship if it was acquired by naturalisation, and that (ii) the deprivation is conducive to public good and that (iii) "the secretary of state has reasonable grounds for believing that the person is able to become a national of another country". The power can only be used against persons who naturalised and not those who are citizens by birth or registration. The intention of the government is to exercise this power while the person is outside the UK so as to prevent his/her return to the UK, which may leave the person stranded in exile abroad without any valid passport to travel with. There are far reaching implications behind a deprivation order as stipulated by the new act. The power which is to be exercised when the person is abroad will prevent the person from entering the UK again and from lodging any appeal in Britain. It may also be, as the ILPA stress that the right to appeal against the deprivation order may not be exercised in time since the individual stripped of his/her citizenship may be unaware of the decision and of his right of appeal. In addition, although the government has been arguing that a person may acquire another citizenship when deprived of his/her British citizenship, in practice as documentary evidence gathered by the ILPA demonstrates, it may prove very difficult to do so in countries known for their strong executive and widespread discretionary power (Ethiopia, Swaziland, Sierra Leone, Zimbabwe, or the Dominican Republic). ${ }^{55}$

\begin{tabular}{|l|l|l|}
\hline Period & Legal texts in force & $\begin{array}{l}\text { Number } \\
\text { deprivations* }\end{array}$ \\
\hline 1973-2002 & $\begin{array}{l}\text { BNA } \mathbf{1 9 4 8} \text { provided that registered citizens could lose their } \\
\text { citizenship if it had been acquired by fraud or } \\
\text { misrepresentation } \\
\text { BNA } 1981 \text { (section 40) stipulates that the Home Secretary can } \\
\text { issue an order of deprivation if he/she is satisfied that } \\
\text { deprivation is 'conducive to public good' but it prohibits the } \\
\text { deprivation order if 'he/she is satisfied that the order would } \\
\text { make a person stateless'. }\end{array}$ & 1 \\
\hline
\end{tabular}

Revue Française de Civilisation Britannique, XXI-1 | 2016 


\begin{tabular}{|c|c|c|}
\hline $2002-2006$ & $\begin{array}{l}\text { Immigration, Nationality and Asylum Act } 2002 \\
\text { Deprivation provisions are extended to all types of citizens } \\
\text { (native-born citizens, registered and naturalised). Grounds for } \\
\text { deprivation: if a person has done anything seriously } \\
\text { prejudicial to the vital interests of the UK except if that would } \\
\text { make the person stateless. Granted a right of appeal against } \\
\text { the deprivation order. } \\
\text { Asylum and Immigration Act 2004: Denaturalization could be } \\
\text { immediate even before the appeal against the deprivation } \\
\text { order had been heard. }\end{array}$ & 1 \\
\hline $2006-2012$ & $\begin{array}{l}\text { Immigration, Nationality and Asylum Act } 2006 \text { (S.4, S.56) } \\
\text { Lower standards for deprivation: "that the Secr. of state can show } \\
\text { that an individual's holding citizenship was not conducive to the } \\
\text { public good" }\end{array}$ & 21 \\
\hline 2013 & Immigration, Nationality and Asylum Act 2006 (S.4, S.56) & 20 \\
\hline $\begin{array}{l}\text { Coalition } \\
\text { government }\end{array}$ & $\begin{array}{l}\text { Immigration Act } 2014 \text { (into force July 2014) } \\
\text { A British person can be deprived of his/her citizenship if it } \\
\text { was acquired by naturalisation, and (ii) the deprivation is } \\
\text { conducive to public good and that (iii) 'the secretary of state } \\
\text { has reasonable grounds for believing that the person is able to } \\
\text { become a national of another country'. }\end{array}$ & $\begin{array}{l}48 \text { as at } 3 \text { June } \\
2014\end{array}$ \\
\hline
\end{tabular}

\section{Conclusion}

Citizenship is traditionally understood as a form of relation, most often as a relation between the citizen and the state, but also as a relation of membership (of a society or political community). But citizenship acts as a point of connection indeed a point of mobilisation - for many individuals and groups who identify themselves as citizens when they act, name themselves as people who would be citizens in demanding citizenship or demand that citizenship be enlarged, enhanced or transformed to engage with other issues, identities and desires. ${ }^{56}$

The concept of citizenship is multidimensional: it confers a legal status, gives social, civil and political rights and is meant to embody the social and cultural identity of the host country. It has been defined by statutory texts, secondary rules and institutional practices which have evolved over the past decade. Since 2010 the attribution of citizenship has been underpinned by considerations which have not varied much from the Labour period. First, citizenship is to be attributed to selected migrants, legal immigrants who have gone through the various stages. Statutory or regulatory provisions do not cater for other categories like students, failed asylum seekers, overstayers or illegal migrants who, nowadays often constitute large groups of those residing in Britain. Second, citizenship is to be attributed after a long journey, there is no easy path. British governments have multiplied the obstacles these migrants have to confront and overcome before being in a position to apply for citizenship and then be granted it. The 
active, solemn, moral and economic commitments expected from migrants are demanded at a very early stage; such expectation reinforces the heavy-handed approach of the British State which intends to keep an ever increasing control over the migrant populations it wants to keep in. Symbolically the ceremonies continue to maintain new citizens in a dependent position and they epitomise the unbalanced relationship between the nation-state and its migrants. Acquiring citizenship has not been conceived as a right but rather as a privilege, based on the eligibility of candidates. Likewise denaturalisation, as recently reformed by the 2014 text, allows for much power to be concentrated in the Home Secretary's hands. In the name of national security, a recurrent argument in governmental rhetoric, successive Home Secretaries have broadened the scope of immigration controls and restricted eligibility to British citizenship with every new law.

Biographie: Catherine Puzzo est maître de conférences en civilisation britannique et appartient au laboratoire de recherche Cultures Anglo-Saxonnes (EA 801) à l'université Toulouse II Jean Jaurès. Elle participe actuellement à un projet de recherche international (Paris III - Rutgers, State University of New Jersey) intitulé SOMI (Securitization of Migrant Integration), une comparaison Grande-Bretagne/Etats Unis de la typologie des mobilisations collectives de communautés immigrées dans le contexte sécuritaire accru de l'après 11 septembre.

\section{BIBLIOGRAPHY}

Anderson, B., "Citizenship: What is it and why does it Matter?", Policy Primer, The Migration Observatory (29 March 2011).

Anderson, B., "Exclusion, Failure and the Politics of Citizenship", RCIS Working Papers, No. 2014/1 (Ryerson University, January 2014).

Andreouli, E. and Dashtipour P., "British citizenship and the 'Other': an Analysis of the Earned Citizenship Discourse”, Journal of Community \& Applied Social Psychology 24 (2014), pp. 100-110.

Advisory Board on Naturalisation and Integration (ABNI), "Progress towards Integration (November 2004-April 2006)", First annual report of the ABNI 2005-2006.

Blair, T., "International Community needs to unite around shared values", Speech on terrorism, Washington DC, 27/05/06. [http://www.labour.org.uk]

Blair, T., "Time for a proper debate on law and order", First lecture in a series of speeches by the Prime Minister, “Our Nation's Future”, 23/6/06. [http://www.number-10.gov.uk]

Blair, T., "Multicultural Britain 'to be celebrated"', Fifth lecture in a series of speeches by the Prime Minister, “Our Nation's Future”, 8/12/06. [http://www.number-10.gov.uk]

Blinder, S., "Naturalisation as a British Citizen: Concepts and Trends", Migration Observatory Briefing, COMPAS (University of Oxford, August 2013).

Bosniak, L., The Citizen and the Alien: Dilemmas of Contemporary Membership (Princeton, Princeton University Press, 2006). 
Byrne, B., "A Local Welcome? Narrations of Citizenship and Nation in UK Citizenship Cremonies", Citizenship Studies 16:3/4 (2012), Special Issue: "Citizenship in the New States of South Eastern Europe", pp. 531-544.

Clarke, J., “New Labour's Citizens: Activated, Empowered, Responsibilized, Abandoned?”, Critical Social Policy 25:4 (2005), pp. 447-443.

Clarke, J., Coll, K., Dagnino E. and Neveu, C., Disputing Citizenship (Bristol, Policy Press, 2014).

Commission for Racial Equality, Citizenship and Belonging: What is Britishness? (London, CRE, 2005).

Condor S., Gibson S. and Abell J., "English Identity and Ethnic Diversity in the Context of UK Constitutional Change", Ethnicities 6:2 (2006), pp.123-158.

Costa-Lascoux, J., «L'intégration 'à la française': une philosophie à l'épreuve des réalités », Revue Européenne des Migrations Internationales 22 (2006), pp. 105-126.

Furedi, F., "Who can pass the spelling test?", Anthology (Commission for Racial Equality, 2006). [ http://www.cre.gov.uk/anthology_15.html]

Gibney, M.J., “'A Very Transcendental Power': Denaturalisation and the Liberalisation of Citizenship in the United Kingdom”, Political Studies 61 (2013), pp. 637-655.

Goldsmith, P., Citizenship: our Common Bond, report commissioned by the Prime Minister (March 2008).

Gray, D. and Griffin, C., "A Journey to Citizenship: Constructions of Citizenship and Identity in the British Citizenship Test”, British Journal of Social Psychology 53 (2014), pp. 299-314.

Hansen, R. "Measures of Integration", Connections (summer 2003), pp. 1-5.

Home Office, Secure Borders, Safe Haven. Integration with Diversity in Modern Britain (London, Stationery Office, February 2002).

Home Office, Citizenship Ceremonies. Consultation Document (London, Stationery Office, 2003).

Home Office, Confident Communities in a Secure Britain. The Home Office Strategic Plan, 2004-2008 (London, Stationery Office, July 2004).

Home Office, Life in the United Kingdom. A Journey to Citizenship (London, Stationery Office, 2006, 2013 (4th edition)).

Home Office, The Path to Citizenship: Next Steps in Reforming the Immigration System (London, Stationery Office, February 2008).

Home Office, GUIDE AN. Naturalisation as a British Citizen. A Guide for Applicants (London, Stationery Office, October 2013).

Hope Cheong, P., Edwards, E., Goulbourne, H. and Solomos J., "Immigration, Social Cohesion and Social Capital: a Critical Review”, Critical Social Policy, 27: 1 (2007), pp. 24-49.

House of Commons, Immigration Bill: Deprivation of British Citizenship (House of Commons Library, SN/HA/6820, 8 May 2014).

Kiwan, D., “A Journey to Citizenship in the United Kingdom”, International Journal on Multicultural Societies 10:1, Special issue "Citizenship Tests in a Post-National Era" (2008), pp. 60-76.

Kiwan, D., “Highly-Skilled 'Guest-Workers' in the UK: Implications for 'Citizenship' in Naturalisation Policy and Integration Policy”, Policy and Society 29 (2010), pp. 333-343.

Kundnani, A., "Integrationism: the Politics of Anti-Muslim Racism”, Race \& Class 48:4 (2007), pp. 24-44. 
Kymlicka, W., “Multicultural Citizenship within Multination States”, Ethnicities 11:3 (2011), pp. 281-302.

Löwenheim, O. and Gazit, O., "Power and Examination: a Critique of Citizenship Tests", Security Dialogue 40:2 (April 2009), pp. 145-167.

Ministry for Justice, The Governance of Britain, Presented to Parliament by the Secretary of State for Justice and Lord Chancellor by Command of Her Majesty (London, July 2007).

Rimmer, M., The Future of Citizenship Ceremonies (Ministry of Justice, 2007).

Sénat, Etude de législation comparée n.150. La formation des étrangers à la langue du pays d'accueil (Sénat, service des études juridiques, septembre 2005).

Spire, A., Accueillir ou reconduire. Enquête sur les guichets de l'immigration (Paris, Editions Raisons d'Agir, 2008).

Stepnisky, J., "Global Memory and the Rhythm of Life", American Behavioral Scientist 48:10 (June 2005), pp. 1383-1402.

Worley, C., "It's not about Race. It's about the Community': New Labour and 'Community Cohesion”", Critical Social Policy 25:4 (2005), pp. 483-496.

Wright, C., "Citizenship Tests in Europe”, International Journal on Multicultural Societies 10:1, Special issue "Citizenship Tests in a Post-National Era" (2008), pp. 1-10.

\section{NOTES}

1. House of Commons' Library, Migration Statistics, Standard Note (SN/SG/6077), 17 June 2014.

2. S. Blinder, "Naturalisation as a British Citizen: Concepts and Trends", Migration Observatory Briefing, COMPAS (University of Oxford, March 2015).

3. D. Gray and C. Griffin, "A Journey to Citizenship: Constructions of Citizenship and Identity in the British Citizenship Test", British Journal of Social Psychology 53 (2014), p. 310.

4. J. Clarke, “New Labour's Citizens: Activated, Empowered, Responsibilized, Abandoned?', Critical Social Policy 25:4 (2005), p. 441.

5. B. Anderson, 'Citizenship: What is it and why does it Matter?' Policy Primer, The Migration Observatory (29 March 2011), p. 3.

6. David Blunkett, quoted in "Citizenship classes for immigrants", The Guardian, 26 October 2001.

7. Home Office, Secure Borders, Safe Haven. Integration with Diversity in Modern Britain (London, Stationery Office, February 2002), chapter 2, p. 35.

8. E. Andreouli and P. Dashtipour, "British Citizenship and the 'Other': an Analysis of the Earned Citizenship Discourse”, Journal of Community \& Applied Social Psychology 24 (2014), pp. 100-110.

9. S. Condor, S. Gibson and J. Abell, "English Identity and Ethnic Diversity in the Context of UK Constitutional Change", Ethnicities 6:2 (2006), p. 126.

10. Ministry for Justice, The Governance of Britain, Presented to Parliament by the Secretary of State for Justice and Lord Chancellor by Command of Her Majesty (London, July 2007), §53.

11. Bosniak, L., The citizen and the Alien: Dilemmas of contemporary membership. Princeton, Princeton University Press, 2006.

12. Green Paper 2007, chapter IV.

13. B. Anderson, "Citizenship: What is it and why does it Matter?", Policy Primer, The Migration Observatory (29 March 2011).

14. See the analysis made by the ILPA (Immigration Law Practitioners' Association), http:// www.ilpa.org.uk. Consulted in July 2014. 
15. The duration of the different stages - temporary residence and probationary citizenship varied from one individual to the other according to their behaviour (e.g. carrying out voluntary work or contributing to the community was meant to speed up the process to proceed from probationary citizenship to full citizenship).

16. B. Anderson, "Citizenship: What is it and why does it Matter?", Policy Primer, The Migration Observatory (29 March 2011), p. 3.

17. "We will not implement Labour's policy of earned citizenship, which was too complicated, bureaucratic and, in the end, ineffective". Home Secretary Theresa May, http://www.workpermit.com/ news/2010-11-08/uk/government-will-not-implement-earned-citizenship.htm. Consulted July 2014.

18. In 2014 the good character requirement came first in the list of reasons for refusals, followed by refusals based on the motive that the residency requirement had not been met (33\%). Other reasons included: incomplete applications (10\%), parent not a British citizen (8\%), delay in replying to the UK Border Agency (6\%) and insufficient knowledge of English (1\%). Source: Home Office, Immigration Statistics July - September 2014, Table cz.09 provided by The Migration Observatory, http://www.migrationobservatory.ox.ac.uk/briefings/naturalisation-british-citizenconcepts-and-trends. Consulted February 2016.

19. Home Office, Nationality Policy Guidance and Casework Instruction. Chapter 18, Annex D: The Good Character Requirement. Version 4.0 (9 December 2013).

20. W. Kymlicka, "Multicultural Citizenship within Multination States", Ethnicities 11:3 (2011), p. 281.

21. Home Office, Citizenship Ceremonies. Consultation Document (London, Stationery Office, 2003), p. 4 .

22. B. Anderson, "Citizenship: What is it and why does it Matter?", Policy Primer, The Migration Observatory (29 March 2011).

23. E. Andreouli and P. Dashtipour, "British Citizenship and the 'Other': an Analysis of the Earned Citizenship Discourse”, Journal of Community \& Applied Social Psychology 24 (2014), p. 102.

24. B. Anderson, "Exclusion, Failure and the Politics of Citizenship", RCIS Working Papers, No. 2014/1 (Ryerson University, January 2014), p. 4.

25. D. Kiwan, "Highly-Skilled 'Guest-Workers' in the UK: Implications for 'Citizenship' in Naturalisation Policy and Integration Policy”, Policy and Society 29 (2010), p. 334.

26. Home Office, The Path to Citizenship: Next Steps in Reforming the Immigration System (London, Stationery Office, February 2008).

27. C. Wright, "Citizenship Tests in Europe", International Journal on Multicultural Societies 10:1, Special issue "Citizenship Tests in a Post-National Era" (2008), pp. 1-10.

28. C. Clarke in the 2004 edition of Life in the UK. Home Office, Life in the United Kingdom. A Journey to Citizenship (London, Stationery Office, 2004, 2006, 2013 (4th edition)).

29. Speech at a seminar on Britishness delivered by G. Brown on 7 February 2007. http:// www.britishpoliticalspeech.org/speech-archive.htm?speech=317. Consulted February 2016.

30. Speech to Conservative party members by D. Cameron on 14 April 2011. http:// www.theguardian.com/politics/2011/apr/14/david-cameron-immigration-speech-full-text. Consulted February 2016.

31. This test is equivalent to the $B 1$ level, the level of an independent user of English (Cf. the Common European Framework of Reference, or CEFR, with its different levels, from A1 with a very basic knowledge to $C 2$ with a very good command of a foreign language).

32. D. Kiwan, "A Journey to Citizenship in the United Kingdom", International Journal on Multicultural Societies 10:1, Special issue "Citizenship Tests in a Post-National Era" (2008), p. 65.

33. Department for Communities and Local Government, The Government's Response to the Commission on Integration and Cohesion (Department for Communities and Local government, February 2008), §3, p. 11. 
34. Home Office's spokesman, quoted in The Guardian, 1 July 2012. http://www.theguardian.com/ uk/2012/jul/01/uk-migrants-patriotic-citizenship-test. Consulted February 2016.

35. See the following articles: T. Brooks, "Failing the Test: Major Review Discovers Serious Problems with Citizenship Test”, https://www.dur.ac.uk/news/newsitem/?itemno=18072 consulted Jumy 2014; B. Porter, "The "Britishness syllabus includes a distorted rendering of British history", The Guardian, 2 February 2013; R. Booth, "From Kipling to Python via Thatcher, the pub quiz to get you a passport", The Guardian, 28 January 2013.

36. E. Andreouli, and P. Dashtipour, "British Citizenship and the 'Other': an Analysis of the Earned Citizenship Discourse", Journal of Community \& Applied Social Psychology 24 (2014), pp. 100-110.

37. J. Costa-Lascoux, "L'intégration 'à la française': une philosophie à l'épreuve des réalités ", Revue Européenne des Migrations Internationales 22 (2006), pp. 105-126.

38. Source: http://www.eu2008.fr/webdav/site/PFUE/shared/ import/1103_Ministerielle_Integration/

conference_integration_041108_Final_declaration_EN.pdf. Consulted April 2009.

39. Prior to 2004 the application process for acquiring citizenship was exclusively conducted by post.

40. David Blunkett, Home Secretary, first citizenship ceremony, Brent Town Hall, 26/02/04.

41. Oath of Allegiance: "I (name) swear by almighty God that on becoming a British citizen I will be faithful and bear true allegiance to her majesty Queen Elisabeth II, her heirs and successors according to law". Affirmation of Allegiance: "I (name) do solemnly, sincerely and truly declare and affirm that on becoming a British citizen I will be faithful and bear true allegiance to her majesty Queen Elisabeth II, her heirs and successors according to law". Pledge of Loyalty: "I (name) will give my loyalty to the United Kingdom and respect its rights and freedoms. I will uphold its democratic values. I will observe its laws faithfully and fulfil my duties and obligations as a British citizen". The affirmation of allegiance is specifically designated for those candidates who are either non-Christian or atheist.

42. Teresa May, House of Commons, 30 January 2014.

43. Home Office, Citizenship Ceremonies. Consultation Document (London, Stationery Office, 2003).

44. In July 2014 a Black Country wide-joint citizenship ceremony was organised by the Walsall, Wolverhampton, Sandwell and Dudley Councils. It was accompanied by the Black Country Anthem "I wow to thee Black Country". Source: Express and Star, 13 July 2014.

45. D. Blunkett, first citizenship ceremony, Brent Hall Town Hall, 26/02/04.

46. Tom McNulty, Immigration minister, 31 October 2005, quoted in: http:// www.independent.co.uk/news/uk/politics/introducing-the-governments-britishness-test-onlyforeigners-need-pass-natives-can-bask-in-ignorance-5348746.html. Consulted February 2016.

47. M. Rimmer, The Future of Citizenship Ceremonies (Ministry of Justice, 2007), p. 4.

48. Other texts include: the Convention on the Reduction of Statelessness 1961 (art.8(1)), the European Convention on Nationality 1997 (art.7(1)) [not yet signed by the UK], and the Guidelines on Statelessness No1 issued by the United Nations High Commissioner for Refugees (20 February 2012).

49. M.J. Gibney, “'A Very Transcendental Power': Denaturalisation and the Liberalisation of Citizenship in the United Kingdom", Political Studies 61 (2013), pp. 637-655.

50. Ibid., p. 638.

51. Peers rejected the initial government proposal whereby a Home Secretary's deprivation order might lead to statelessness putting the UK in breach of its international obligations. For the full version of the 'ping pong' debates between the Lords and the Commons see House of Commons, Immigration Bill: Deprivation of British Citizenship (House of Commons' Library, SN/ HA/6820, 8 May 2014). See also ILPA briefing, 12 May 2014,. http://www.ilpa.org.uk/ resources.php/26335/immigration-bill-ilpa-briefing-for-ping-pong-in-the-house-of-lords-12may-2014 consulted February 2016. 
52. United Kingdom Supreme Court 62, 9 October 2013.

53. Immigration Bill 2014, Fact Sheet: deprivation of citizenship (clause 60), https://www.gov.uk/ government/uploads/system/uploads/attachment_data/file/277578/

Factsheet_15_Deprivation.pdf. Consulted February 2016.

54. M. Gibney quotes Hillary Clinton's words in Congress to support legislation to denaturalize US citizens when convicted of terrorist acts. M.J. Gibney, “'A Very Transcendental Power': Denaturalisation and the Liberalisation of Citizenship in the United Kingdom", Political Studies 61 (2013), p. 638.

55. ILPA, Immigration Bill House of Commons' Consideration of Lords' Amendments 7 May 2014: further briefing from the Immigration Law Practitioners' Association, www.ilpa.org.uk.

56. J. Clarke, K. Coll, E. Dagnino and C. Neveu, Disputing Citizenship (Bristol, Policy Press, 2014), p. 1.

\section{ABSTRACTS}

In February 2009 Gordon Brown's government promoted the concept of 'earned citizenship' which is based on the principle that British citizenship is a privilege that must be earned, that applying for UK citizenship is a long journey and that migrants have to undergo a series of tests before being eligible to get naturalized. Successive governments have further reinforced the criteria to meet with the introduction of a renewed version of the UK Life Test, the reinforcement of the probationary citizenship period and the requirement to have better language skills than before. Ten years after their creation, citizenship ceremonies conceived as the best way for newly registered citizens to show that they have a shared understanding of what it means to be British are still apprehended as a means to give a political and ideological significance to the attribution of citizenship through the development of a national statement of values. Simultaneously the power to deprive somebody of his citizenship has been extended in a context of increased securitization of migration. Home Secretaries have been exercising more and more their power to strip people of their British citizenship and withdraw passport facilities for those individuals suspected of having been involved in terrorist activities or considered to be a threat to national security.

En février 2009 le gouvernement de Gordon Brown promut le concept de 'citoyenneté acquise' basée sur le principe que la nationalité britannique est un privilège à conquérir, que le processus de naturalisation est long (introduction de diverses phases préparatoires) et que les futurs citoyens doivent réussir plusieurs sortes de tests (UK life test, test de langue). En outre, dix ans après leur introduction, les cérémonies de naturalisation sont plus que jamais un moyen de donner une valeur politique et idéologique à l'attribution de la nationalité par le biais de valeurs nationales communes. Enfin et parallèlement au renforcement des conditions d'accès à la nationalité les gouvernements britanniques ont étendu les critères permettant la déchéance de nationalité et ce, dans un contexte sécuritaire renforcé. 
INDEX

Mots-clés: nationalité, naturalisation, déchéance de nationalité, cérémonies de naturalisation

Keywords: citizenship, naturalization, denaturalization, citizenship ceremonies

AUTHOR

CATHERINE PUZZO

CAS (EA 801), Université Toulouse-Jean Jaurès 